\title{
The Serum Levels of LD and CRP in Patients of Coal Workers' Pneumoconiosis with Chronic Obstructive Pulmonary Disease
}

Jong Seong Lee, Jae Hoon Shin, YouLim Lee, JinEe Baek, Byung-Soon Choi

Occupational Lung Diseases Research Institute, Korea Workers' Compensation \& Welfare Service, Incheon, Korea

\section{만성폐쇄성폐질환을 동반한 탄광부진폐증자의 혈청 중 LD 및 CRP 농도}

이종성, 신재훈, 이유림, 백진이, 최병순

근로복지공단 직업성폐질환연구소

\begin{abstract}
Coal workers' pneumoconiosis (CWP) and chronic obstructive pulmonary disease (COPD) are characterized as chronic inflammation of the lung in miners exposed to coal mine dust. The aim of the present study was to compare the levels of serum lactate dehydrogenase (LD) and C-reactive protein (CRP) as the inflammatory indices between subjects with CWP and those with CWP and COPD (CWP+COPD), among a total of 97 subjects (27 control, 40 CWP, and 30 CWP+COPD patients). The mean levels of serum LD (165.7 vs $184.6 \mathrm{U} / \mathrm{L}, p=0.016)$ and CRP (0.08 vs 0.15 $\mathrm{mg} / \mathrm{dL}, p=0.002)$ in subjects with CWP were higher than those of in subjects without CWP. The mean level of serum CRP ( 0.10 vs $0.19 \mathrm{mg} / \mathrm{dL}, p=0.008$ ) in subjects with COPD was higher than that in subjects without COPD. In an analysis of covariance adjusted by age, the mean level of serum CRP showed statistical significance among the study groups, control, CWP, and CWP+COPD (0.07 vs 0.13 vs $0.19 \mathrm{mg} / \mathrm{dL}, p=0.005$ ); the mean level of serum CRP in the CWP+COPD group was significantly higher than that of the control group $(p=0.001)$. The results suggest that a high level of CRP in the serum may be associated with CWP and COPD in retired coal miners.
\end{abstract}

Key words: Coal workers' pneumoconiosis, Chronic obstructive pulmonary disease, Lactate dehydrogenase, C-reactive protein

This is an Open Access article distributed under the terms of the Creative Commons Attribution Non-Commercial License (http://creativecommons.org/licenses/by-nc/4.0) which permits unrestricted non-commercial use, distribution, and reproduction in any medium, provided the original work is properly cited.

Copyright (C) 2017 The Korean Society for Clinical Laboratory Science. All rights reserved.
Corresponding author: Jong Seong Lee Occupational Lung Diseases Research Institute, Korea Workers' Compensation \& Welfare Service, 478 Munemi-ro, Bupyeong-gu, Incheon 21417, Korea Tel: 82-32-540-4981

Fax: 82-32-540-4997

E-mail: ljs5075@kcomwel.or.kr

Received: May 24, 2017

Revised 1 $1^{\text {st: June } 21,2017}$

Revised $2^{\text {nd }}$ : June 30, 2017

Revised 3 ${ }^{\text {rd: }}$ July 3, 2017

Revised $4^{\text {th }}$ : July 11,2017

Accepted: July 11, 2017

\section{서 론}

석면, 결정형 유리규산 및 석탄분진과 같은 분진의 노출은 탄 광부진폐증(coal workers' pneumoconiosis, CWP), 진행성 폐 섬유화, 폐포염 및 기관지확장증 등을 유발한다[1]. 특히 결 정형 유리규산은 국제암연구소(International Agency for
Research on Cancer, IARC)에서 1급 발암물질로 규정하고 있 다[2]. 만성폐쇄성폐질환(chronic obstructive pulmonary disease, COPD)은 지속적인 폐환기 장해를 특징으로 하는 질 병으로 대개 진행성이며 독성 분진 또는 가스흡입으로 인한 폐 기도의 만성 염증성 반응과 관련이 있다[3]. 석탄분진 노출 근로 자에서 $\mathrm{CWP}$ 와 $\mathrm{COPD}$ 는 중요한 직업성 질환으로[4], 우리나라 
에서도 이러한 광산 근로자 및 이직 근로자에 대하여 '진폐의 예 방 및 진폐근로자의 보호 등에 관한 법률' 등의 특별법으로 진 단, 치료, 요양 및 보상을 관리하고 있다[5].

석탄분진을 흡입할 경우, 폐 세포의 손상과 섬유화로 인해 지 속적인 폐에 흥터를 남기는 CWP를 일으킬 수 있다[6]. 석탄에 는 결정형 유리규산이 포함되어 있기 때문에 CWP 역시 결정형 유리규산에 의해 발병되는 규폐증(silicosis)과 비슷한 염증기 전을 가지며, 이로 인해 폐기능 손실을 유발한다[1]. CWP는 치 료가 불가능하기 때문에 증상의 조기진단을 위해 전향적 예측 지표(prospective markers)로서 생물학적 반응의 이용 가능성 을 연구하는 것이 중요하다[7]. CWP와 COPD를 진단하기 위 하여 흥부방사선학적 소견에 의한 형태학적 변화와 폐기능 검 사와 같은 기능적 변화에 대한 진단방법 등에 의존하고 있으나, 이러한 소견 및 변화는 이미 심각하게 섬유화가 진행되어야만 진단이 가능하다. 또한 분진노출이 중단된 후에도 흥부방사선 학적 진폐 병형과 폐기능 손실이 진행되는 것으로 볼 때, 이러한 분진에 의한 생물학적 활성이 지속된다고 볼 수 있다[8]. 유리규 산은 임계치를 한번이라도 초과할 경우 추가적인 노출이 없어 도 폐질환이 진행되기 때문에, 이러한 유해인자에 노출되었던 이직근로자 역시 지속적인 관리가 중요하다[9].

Lactate dehydrogenase (LD)는 세포 손상지표로서 이용될 수 있는데, 석탄광부에서 혈청 중 $\mathrm{LD}$ 농도가 증가하며, 노출이 중단되더라도 그 농도가 오랫동안 유지된다고 하였고[10], 질 병의 진행 상태와 관련성이 있다고 하였다[7]. C-reactive protein (CRP)은 진폐증에서 농도가 증가하는 염증성 cytokine 인 interleukin-6 (IL6)과 밀접한 관련성이 있으며[11], COPD 환자에서도 정상 대조군에 비해 혈중 $\mathrm{CRP}$ 농도가 증가하고, 이 러한 원인 중에는 일정 부분 IL6와 관련성이 있다고 하였다[12]. 이와같이 CWP나 COPD 등과같은 폐 세포의 손상으로 인해 세 포막 혹은 세포내 효소 등의 성분들이 세포 외액으로 유리될 수 있기 때문에, 이러한 효소들은 세포 손상 지표로 이용될 수 있는 데, 분진으로 인한 폐의 염증여부를 판단하기 위해 세포 손상 지 표인 LD와 CRP 등의 혈중 농도가 이용될 수 있다고 하였다[7]. 그러나 $\mathrm{COPD}$ 와 같은 폐기능 손실이 동시에 나타나는 $\mathrm{CWP}$ 에 서의 혈중 $\mathrm{LD}$ 및 $\mathrm{CRP}$ 농도에 대한 연구는 보고된 바 없다.

본 연구는 CWP 및 COPD 수반한 CWP 집단을 대상으로 혈 중 $\mathrm{LD}$ 와 $\mathrm{CRP}$ 농도와의 비교를 통해 이러한 질병과 생체지표간 의 특성을 보고자 하였다.

\section{대상 및 방법}

\section{1. 연구 대상}

진폐건강진단을 위해 내원한 남자 탄광부 이직근로자 163 명 중 간기능 관련 진단항목(aspartate aminotransferase, alanine aminotransferase 또는 gamma-glutamyl transpeptidase)의 참고치 이상을 나타낸 66명을 제외한 97명을 최종 연구대상자 로 하였다. 대조군(non-CWP 및 non-COPD)은 27명이었고 CWP군은 70명이었는데, CWP 군은 I형 37명, II형 19명 III형 1명이었고, 진행성 폐섬유화증(progressive massive fibrosis, $\mathrm{PMF}$ ) 13 명 이었다. 또한 CWP군 중에서 CWP만 있는 대상자는 40 명이었고 $\mathrm{COPD}$ 를 동반한 집단(CWP+COPD군)은 30명이 었다.

\section{CWP 및 $\mathrm{COPD}$ 진단}

$\mathrm{CWP}$ 의 진단은 국제노동기구(International Labor Office, ILO)에서 정하고 있는 방법에 따라 연구대상자의 흥부영상에 대하여 근로복지공단 진폐심사위원회의 영상의학 전문의 2 인 에 의한 합의판정으로 하였다[13]. 폐기능 검사는 폐기능 검사 기(Vmax22, SensorMedics, USA)를 이용하여 미국흥부학회 (American Thoracic Society, ATS)/유럽호흡기학회(European Respiratory Society, ERS)에서 권장하는 방법으로 시행하였는 데[14], 노력성 폐활량(forced vital capacity, FVC) 및 노력성 일초간 호기량(forced expiratory volume in one second, $\mathrm{FEV}_{1}$ )을 측정하였고, 각각의 예측치는 Morris 방식으로 계산하 였다[15]. COPD의 진단은 대한결핵 및 호흡기학회(Korea Academy of Tuberculosis and Respiratory diseases, KATRD) 에서 정하고 있는 일초율 $\left(\% \mathrm{FEV}_{1} / \mathrm{FVC}\right) 70 \%$ 미만이고, 속효성 $\beta 2$-기관지 확장제를 흡입한 후 $\mathrm{FEV}_{1}$ 이 $200 \mathrm{~mL}$ 및 $12 \%$ 미만으 로 증가한 경우로 하였다[16]. 혈청 중 $\mathrm{LD}$ 와 CRP는 채혈 즉시 혈청분리한 후 자동생화학분석기(7080, Hitachi Technology Co., Japan)으로 분석하였다. 연구대상자에 대하여 면접조사를 통하여 나이, 체질량지수(body mass index, BMI), 분진노출기 간, 흡연여부, 당뇨병 및 고혈압 여부 등의 일반적 특성을 조사 하였다. 연구대상자에 대하여 연구참여동의서에 서명(informed consent) 받았으며, 근로복지공단 직업성폐질환연구소 기관생 명윤리위원회(2011-30-02) 심의완료 후 연구를 진행하였다.

\section{3. 통계분석}

모든 통계분석은 SPSS 17.0 (SPSS, Chicago, IL, USA)으로 수행하였는데, 혈중 $\mathrm{LD}$ 는 정규분포 하였고, $\mathrm{CRP}$ 는 1 /제곱근 
(square root)으로 변환 후 정규분포 하였다. 비교군의 일반적 특성은 $\chi^{2}$-test, t-test 및 분산분석(ANOVA)으로 비교분석하였 고, 연구집단 간의 $\mathrm{LD}$ 및 $\mathrm{CRP}$ 의 평균 농도는 혼란변수인 연령을 통제한 후 공분산분석(analysis of covariance, ANCOVA)으로 검증하였다. 각 분석의 통계적 유의수준은 $p<0.05$ 로 하였다.

\section{결 과}

\section{1. 일반적 특성}

연구대상자의 일반적 특성은 Table 1과 같다. 연구집단간 $\mathrm{BMI}$, 분진노출기간, \% FVC, 흡연여부, 당뇨병 및 고혈압의 차이

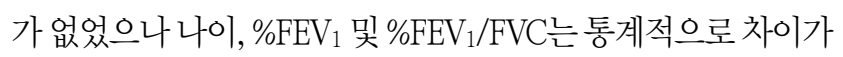
있었다.

\section{2. 혈중 LD 및 $\mathrm{CRP}$ 농도}

혈중 $\mathrm{LD}$ 및 $\mathrm{CRP}$ 농도는 연령, $\mathrm{BMI}$, 분진노출기간, 흡연, 당뇨 병 및 고혈압 여부 등 일반적 특성에 따른 차이가 없었다. CWP 군의 혈중 $\mathrm{LD}$ 평균 농도(165.7 U/L vs 184.6 U/L, $p=0.016$ )와 $\mathrm{CRP}$ 평균 농도가 non-CWP군 보다 높았다 $(0.08 \mathrm{mg} / \mathrm{dL}$ vs 0.15 $\mathrm{mg} / \mathrm{dL}, p=0.002)$. $\mathrm{COPD}$ 군에서의 혈중 $\mathrm{CRP}$ 평균 농도는 non-COPD군보다 높았으나 $(0.10 \mathrm{mg} / \mathrm{dL}$ vs $0.19 \mathrm{mg} / \mathrm{dL}$, $p=0.008) \mathrm{LD}$ 평균 농도는 두 집단간 차이가 없었다(177.1 U/L vs 184.2 U/L, $p=0.359$ ) (Table 2).

연구집단간 통계적 유의성을 보였던 연령을 통제한 공분산
분석에서, 혈중 $\mathrm{CRP}$ 평균농도는 대조군, $\mathrm{CWP}$ 군 및 $\mathrm{CWP}+\mathrm{COPD}$ 군 간에 통계적으로 유의하게 증가하였는데( 0.07 vs 0.13 vs $0.19 \mathrm{mg} / \mathrm{dL}, p=0.005)$, 대조군과 CWP군은 통계적으로 유의 한 차이가 없었지만 $\mathrm{CWP}+\mathrm{COPD}$ 군은 대조군에 비해 통계적 으로 유의하게 높았다 $(p=0.001)$. 혈중 $\mathrm{LD}$ 의 평균 농도는 대조 군에 비해 $\mathrm{CWP}$ 군과 $\mathrm{CWP}+\mathrm{COPD}$ 군에서 높은 경향을 보였지 만 통계적으로 유의하지는 않았다(167.7 vs 184.6 vs 182.7 $\mathrm{U} / \mathrm{L}, p=0.173$ ) (Table 3).

\section{고 찰}

석탄분진과 결정형 유리규산에 감수성이 있는 근로자가 이 러한 분진에 노출될 경우 여러 가지 폐질환으로 진행될 수 있는 데, 이러한 질병에는 고전적 의미의 진폐증을 비롯한 결절성 간 질성 폐질환을 비롯하여, 진행성 폐섬유화, 폐부종 및 만성기관 지염을 포함한 $\mathrm{COPD}$ 등을 일으킬 수 있다[8,17]. 선행연구에 따르면 결정형 유리규산 또는 석탄분진을 흡입할 경우 결정형 섬유성 폐조직 반응이 나타난다고 보고하고 있다[8].

CWP는 폐포 대식세포와상피세포의 활성과 관련이 있는 만 성염증의 특징을 가진다[18]. 결정형 유리규산 또는 석탄분진 의 노출이 중단된 이직근로자에서도 흥부방사선학적 진폐 병형 과 폐기능의 손실이 진행되는 것으로 볼 때, 이러한 분진에 의한 생물학적 활성이 지속된다고 볼 수 있다[8]. 그러나 현재 CWP 와 $\mathrm{COPD}$ 의 진단과 질병의 정도는 흥부방사선 영상 판독과

Table 1. General characteristics of the study subjects

\begin{tabular}{|c|c|c|c|c|}
\hline Parameters & Control $(\mathrm{N}=27)$ & CWP $(N=40)$ & CWP+COPD $(\mathrm{N}=30)$ & $p$-values \\
\hline Age $(y r s)^{*}$ & $59.1 \pm 6.4$ & $65.1 \pm 7.5$ & $68.5 \pm 5.8$ & $<0.001$ \\
\hline BMI $\left(\mathrm{kg} / \mathrm{m}^{2}\right)^{\star}$ & $24.4 \pm 2.3$ & $23.3 \pm 3.1$ & $23.6 \pm 2.7$ & 0.309 \\
\hline Exposure period $(\mathrm{yrs})^{\star}$ & $14.9 \pm 8.6$ & $18.5 \pm 8.1$ & $17.5 \pm 7.8$ & 0.204 \\
\hline$\% F V C$ predicted & $95.7 \pm 11.8$ & $94.0 \pm 13.3$ & $94.5 \pm 11.9$ & 0.852 \\
\hline$\% F V_{1}$ predicted & $103.8 \pm 15.7$ & $104.0 \pm 15.9$ & $85.2 \pm 13.3$ & $<0.001$ \\
\hline$\% F E V_{1} / F V C$ ratio & $78.0 \pm 4.5$ & $77.6 \pm 5.7$ & $62.1 \pm 6.8$ & $<0.001$ \\
\hline \multicolumn{5}{|l|}{ Smoking, No. $(\%)^{\dagger}$} \\
\hline No & $19(70.4)$ & $24(60.0)$ & $20(66.7)$ & 0.664 \\
\hline Yes & $8(29.6)$ & $16(40.0)$ & $10(33.3)$ & \\
\hline \multicolumn{5}{|l|}{ Diabetes, No. $(\%)^{\dagger}$} \\
\hline No & $23(85.2)$ & $36(90.0)$ & $26(86.7)$ & 0.662 \\
\hline Yes & $4(14.8)$ & $4(10.0)$ & $4(13.3)$ & \\
\hline \multicolumn{5}{|l|}{ Hypertension, No. $(\%)^{\dagger}$} \\
\hline No & $18(66.7)$ & $26(65.0)$ & $24(80.0)$ & 0.359 \\
\hline Yes & $9(33.3)$ & $14(35.0)$ & $6(20.0)$ & \\
\hline
\end{tabular}

Arithmetic mean \pm Arithmetic standard deviation.

${ }^{*}$ Calculated by ANOVA.

${ }^{\dagger}$ Calculated by $\chi^{2}$-test.

Abbreviations: CWP, coal workers' pneumoconiosis; COPD, chronic obstructive pulmonary diseases; BMI, body mass index; FVC, forced vital capacity; $\mathrm{FEV}_{1}$, forced expiratory volume in 1 second. 
Table 2. Concentrations of serum LD and CRP according to general characteristics

\begin{tabular}{|c|c|c|c|c|c|c|}
\hline \multirow{2}{*}{\multicolumn{2}{|c|}{ Characteristics }} & \multirow{3}{*}{$\frac{N}{25}$} & \multicolumn{2}{|c|}{$L D^{*}$} & \multicolumn{2}{|c|}{$\mathrm{CRP}^{\dagger}$} \\
\hline & & & \multirow{2}{*}{$\frac{U / L}{175.9(29.0)}$} & \multirow{2}{*}{$\begin{array}{c}p \text {-values } \\
0.055\end{array}$} & \multirow{2}{*}{$\begin{array}{c}\mathrm{mg} / \mathrm{dL} \\
0.11(0.62)\end{array}$} & \multirow{2}{*}{$\begin{array}{c}p \text {-values } \\
0.582\end{array}$} \\
\hline Age (yrs) & $\sim 59$ & & & & & \\
\hline & $60 \sim 69$ & 51 & $174.4(32.4)$ & & $0.11(0.38)$ & \\
\hline & $70 \sim$ & 21 & $195.5(43.7)$ & & $0.15(0.76)$ & \\
\hline \multirow[t]{2}{*}{$\mathrm{BMI}\left(\mathrm{kg} / \mathrm{m}^{2}\right)$} & $<25$ & 66 & $178.3(32.6)$ & 0.680 & $0.13(0.60)$ & 0.354 \\
\hline & $\geq 25$ & 31 & $181.5(40.2)$ & & $0.10(0.34)$ & \\
\hline \multirow[t]{3}{*}{ Exposure period (yrs) } & $\sim 9$ & 14 & $168.1(31.7)$ & 0.355 & $0.14(1.03)$ & 0.758 \\
\hline & $10 \sim 19$ & 45 & $183.5(39.1)$ & & $0.12(0.35)$ & \\
\hline & $20 \sim$ & 38 & $178.5(30.6)$ & & $0.11(0.62)$ & \\
\hline \multirow[t]{2}{*}{ Smoking } & No & 63 & $185.0(37.0)$ & 0.029 & $0.11(0.43)$ & 0.323 \\
\hline & Yes & 34 & $168.8(28.6)$ & & $0.14(0.61)$ & \\
\hline \multirow[t]{2}{*}{ Diabetes } & No & 85 & $179.3(32.7)$ & 0.958 & $0.12(0.48)$ & 0.505 \\
\hline & Yes & 12 & $179.8(50.5)$ & & $0.14(0.49)$ & \\
\hline \multirow[t]{2}{*}{ Hypertension } & No & 68 & $178.9(34.4)$ & 0.843 & $0.12(0.42)$ & 0.635 \\
\hline & Yes & 29 & $180.4(37.0)$ & & $0.13(0.72)$ & \\
\hline \multirow[t]{2}{*}{ CWP } & No & 27 & $165.7(27.1)$ & 0.016 & $0.08(0.33)$ & 0.002 \\
\hline & Yes $^{\ddagger}$ & 70 & $184.6(36.4)$ & & $0.15(0.68)$ & \\
\hline \multirow[t]{2}{*}{ COPD } & No & 67 & $177.1(32.3)$ & 0.359 & $0.10(0.48)$ & 0.008 \\
\hline & Yes & 30 & $184.2(40.6)$ & & $0.19(0.59)$ & \\
\hline
\end{tabular}

*Arithmetic mean (Arithmetic standard deviation).

${ }^{\dagger}$ Geometric mean (Geometric standard deviation).

${ }^{\ddagger}$ ILO category of chest radiographs: I, 37 subjects; II, 19 subjects; III, 1 subject; progressive massive fibrosis, 13 subjects. $p$-values were calculated by ANOVA or t-test.

Abbreviations: CWP, coal workers' pneumoconiosis COPD, chronic obstructive pulmonary diseases.

Table 3. Serum LD and CRP among the study groups

\begin{tabular}{clcccc}
\hline Age-adjustment & Parameters & Control $(\mathrm{N}=27)$ & CWP $(\mathrm{N}=40)$ & CWP+COPD $(\mathrm{N}=30)$ & $p$-values \\
\hline Before $^{\star}$ & $\mathrm{LD}(\mathrm{U} / \mathrm{L})^{\dagger}$ & $165.7(5.22)$ & $184.9(5.30)$ & $184.2(7.41)$ & 0.056 \\
& $\mathrm{CRP}(\mathrm{mg} / \mathrm{dL})^{\S}$ & $0.08(8.9)$ & $0.12(32.6)$ & $0.19(17.8)$ & 0.002 \\
After $^{\dagger}$ & $\mathrm{LD}(\mathrm{U} / \mathrm{L})^{\dagger}$ & $167.7(7.21)$ & $184.6(5.45)$ & $182.7(6.63)$ & 0.173 \\
& $\mathrm{CRP}(\mathrm{mg} / \mathrm{dL})^{\S}$ & $0.07(12.1)$ & $0.13(21.1)$ & $0.19(14.3)$ & 0.005 \\
\hline
\end{tabular}

*Calculated by ANOVA test.

${ }^{\dagger}$ Calculated by analysis of covariance (ANCOVA) adjusted by age.

${ }^{\ddagger}$ Arithmetic mean (arithmetic standard error).

${ }^{\S}$ Geometric mean (geometric standard error).

"In ANCOVA test adjusted by age, the $p$-value of serum CRP between control and CWP+COPD group was 0.001, but there was no statistical significance between control and CWP group.

Abbreviations: CWP, coal workers' pneumoconiosis (CWP); COPD, chronic obstructive pulmonary diseases.

PFT에 의존하고 있는 실정이다. 따라서 흥부영상에서의 비가 역적 변화와 폐기능의 손실이 나타나기 전에 예후를 판단할 수 있는 유용한 생체지표에 대한 연구가 필요하다[7]. 본 연구에서 는 간기능 손상에 의한 혈중 $\mathrm{LD}$ 및 $\mathrm{CRP}$ 농도의 영향을 배제하기 위해 간기능 손상지표의 참고치를 초과한 경우 연구대상자에서 제외하였다.

폐질환과 혈중 $\mathrm{LD}$ 의 활성증가 간의 관련성에 대한 선행 고찰 연구[19]에서 폐에서의 염증, 세포손상, 개질 및 섬유화와 같은 간질성 폐질환인 진폐증과 세포 손상 및 사멸과 관련이 있는 $\mathrm{COPD}$ 의 경우에 혈청 중의 $\mathrm{LD}$ 농도가 증가한다고 하였다. 이번
연구에서 혈중 $\mathrm{LD}$ 농도는 연령을 통제하지 않았을 경우 CWP군 에서 유의하게 높았으나(165.7 vs 184.6, $p=0.016$ ), 연령을 통 제한 후 대조군에 비해 $\mathrm{CWP}$ 군과 $\mathrm{CWP}+\mathrm{COPD}$ 군에서 높은 경 향을 보였으나 통계적으로 유의하지는 않았다(167.7 vs 184.6 vs $182.7 \mathrm{U} / \mathrm{L}, p=0.173)$. 이러한 결과는 탄광부에서 혈청 중 $\mathrm{LD}$ 농도가 증가한다고 보고한 Cobben 등[10]의 연구결과와 일치 하였다. 이번 연구에서 혈청 중 $\mathrm{LD}$ 농도는 $\mathrm{COPD}$ 여부에 따른 농도의 차이는 보이지 않았다 $(p=0.359) . \mathrm{LD}$ 는 5 가지의 이성체 의 형태가 존재하는데 특히 폐조직에는 LD3과 관련이 있는 것 으로 알려져 있다. Cobben 등[10]은 석탄분진 노출자에서 
$\mathrm{FEV}_{1}$ 이 감소하고 혈청 중 $\mathrm{LD}$ 농도가 증가하며 특히 $\mathrm{LD} 3$ 활성증 가와 관련성이 있다고 하였다. 따라서 향후 연구대상자를 확대 하고 $\mathrm{CWP}$ 및 $\mathrm{COPD}$ 등의 합병증과 $\mathrm{LD}$ 이성체 간의 관련성에 대한 연구가 필요하다.

혈중 CRP는 생체내 염증성 변화를 반영하는 단백질로써 대 식세포와 T-cell 등의 의한 IL6와 연관되어 간에서 합성되는데 [20], CWP환자에 대한 기본적인 건강진단 검사항목으로도 많 이 이용되고 있다. Fernandez Rego 등[21]의 선행 연구에 의하 면 진폐증 및 진행성 진폐증의 경우 대조군에 비해 혈중 $\mathrm{CRP}$ 농 도가 증가하기 때문에 질병의 정도에 대한 생체지표로써 유용 하다고 하였고, Agusti 등[22]은 COPD환자의 혈중 CRP 농도 는 흡연 및 비흡연 대조군보다 유의하게 높았고, 흡연 대조군 역 시 비흡연 대조군보다 증가한다고 하였다. 이번 연구에서 혈중 $\mathrm{CRP}$ 농도는 분산분석에서 $\mathrm{CWP}$ 군(0.08 vs $0.15 \mathrm{mg} / \mathrm{dL}$, $p=0.002)$ 및 COPD군(0.10 vs $0.19 \mathrm{mg} / \mathrm{dL}, p=0.008)$ 에서 유 의하게 높았다. 연령을 통제한 후에도 대조군, CWP군 및 $\mathrm{CWP}+\mathrm{COPD}$ 군 간에 통계적으로 유의하게 증가하였는데(0.07 vs 0.13 vs $0.19 \mathrm{mg} / \mathrm{dL}, p=0.005)$, 대조군과 CWP군은 통계적 유의성이 없었는데 비해 $\mathrm{CWP}+\mathrm{COPD}$ 군에서 통계적으로 유의 하게 증가하였다 $(p=0.001)$.

$\mathrm{COPD}$ 를 수반한 CWP 환자에 대한 혈중 $\mathrm{LD}$ 및 $\mathrm{CRP}$ 에 대한 선행연구가 없어 직접적인 비교는 불가능하였지만, 이번 연구 결과 혈중 $\mathrm{LD}$ 농도는 통계적으로 유의성은 없지만 $\mathrm{COPD}$ 합병 증과 관계없이 CWP 집단에서 농도가 증가하는 것으로 보이는 데, 통계적 유의성이 떨어지는 원인으로는 CWP 군에 속한 연구 대상자 중에 염증의 진행이 있는 PMF가 CWP군 70명 중 약 $19 \%$ 인 13명인데 비해 나머지는 폐섬유화 흔적만 있는 단순진 폐증(simple pneumoconiosis)이었기 때문으로 판단된다. 혈 중 $\mathrm{CRP}$ 농도는 $\mathrm{CWP}$ 집단에서도 농도가 증가하지만 $\mathrm{COPD}$ 합 병증이 있을 경우 더욱 증가하는 것으로 보인다. 비록 $\mathrm{CRP}$ 가 급 성기 염증변화에 대한 생체지표이지만 만성적 염증의 특성을 나타내는 $\mathrm{COPD}$ 를 동반한 $\mathrm{CWP}$ 군에서도 $\mathrm{CRP}$ 농도가 증가하 는 것으로 판단된다.

이번 연구결과 혈청 중의 $\mathrm{LD}$ 와 $\mathrm{CRP}$ 농도는 $\mathrm{CWP}$ 여부에 대 해 민감도와 특이도가 높지는 않지만 진단지표로서 유용하였 고, 특히 $\mathrm{CRP}$ 는 $\mathrm{COPD}$ 를 동반한 $\mathrm{CWP}$ 환자에서 더욱 농도가 증 가한다는 것을 알 수 있었다.

\section{요 약}

탄광부진폐증(CWP)과 만성폐쇄성폐질환(COPD)은 석탄
분진에 노출되는 탄광부의 폐에서 나타나는 만성적 폐 염증의 특성을 가진다. 이번 연구의 목적은 대조군 27명, CWP 40명, $\mathrm{COPD}$ 를 동반한 CWP 30명 등 총97명을 대상으로 염증지표로 서 혈청 중의 $\mathrm{LD}$ 와 $\mathrm{CRP}$ 수준을 비교하고자 하였다. 혈청 중의 $\mathrm{LD}$ 평균 농도(165.7 vs 184.6 U/L, $p=0.016)$ 와 $\mathrm{CRP}$ 평균 농도 (0.08 vs $0.15 \mathrm{mg} / \mathrm{dL}, p=0.002)$ 는 CWP군에서 유의하게 높았 다. 혈청 중의 CRP 평균 농도(0.10 vs $0.19 \mathrm{mg} / \mathrm{dL}, p=0.008)$ 는 $\mathrm{COPD}$ 군에서 높았다. 연령을 통제한 공분산분석에서, 혈청 중 $\mathrm{CRP}$ 평균 농도는 대조군, $\mathrm{CWP}$ 군 및 $\mathrm{CWP}+\mathrm{COPD}$ 군 간에 통계 적으로 유의한 차이가 있었으며(0.07 vs 0.13 vs $0.19 \mathrm{mg} / \mathrm{dL}$, $p=0.005), \mathrm{CWP}+\mathrm{COPD}$ 군의 혈청 $\mathrm{CRP}$ 평균 농도가 대조군보 다 유의하게 높았다 $(p=0.001)$. 이러한 결과는 높은 수준의 혈청 중 $\mathrm{CRP}$ 는 탄광부 이직근로자에서의 $\mathrm{CWP}$ 및 $\mathrm{COPD}$ 와 관련이 있는 것으로 보인다.

\section{Acknowledgements: None}

Funding: None

Conflict of interest: None

\section{REFERENCES}

1. Schins RPF and Borm PJA. Mechanisms and mediators in coal dust induced toxicity: A review. Am Occup Hyg. 1999; 43(1): 7-33.

2. International Agency for Research on Cancer. IARC Monograph on the evaluation of the carcinogenic risk of chemicals to humans. In: Silica, some silicates, coal dust and para-aramid fibrils. Geneva, Switzerland. IARC Press; 1997. Vol. 68.

3. Vestbo J, Hurd SS, Agusti AG, Jones PW, Vogelmeier C, Anzueto A, et al. Global strategy for the diagnosis, management, and prevention of chronic obstructive pulmonary disease: GOLD executive summary. Am J Respir Crit Care Med. 2013;187(4): 347-365.

4. Meijers JM, Swaen GM, Slangen JJ. Mortality of Dutch coal miners in relation to pneumoconiosis, chronic obstructive pulmonary disease, and lung function. Occup Environ Med. 1997; 54(10):708-713.

5. National Law Information Center. Act on the prevention of pneumoconiosis and protection, etc., of pneumoconiosis workers. Sejong: Korea Ministry of Government Legislation; 2016. No. 13911.

6. Castranova V. From coal mine dust to quartz: Mechanism of pulmonary pathology. Inhal Toxicol. 2000;12(Suppl 3):7-14.

7. Gulumian M, Borm PJA, Vallyathan, Castranova V, Donaldson K, Nelson G, et al. Mechanistically identified suitable biomarkers of exposure, effect, and susceptibility for silicosis and coal-worker's pneumoconiosis: a comprehensive review. J Toxicol Environ Health B Crit Rev. 2006;9(5):357-395. 
8. Cohen RA, Patel A, Green FHY. Lung disease caused by exposure to coal mine and silica dust. Semin Respir Crit Care Med. 2008;29(6):651-661.

9. Porter DW, Hubbs AF, Mercer R, Robinson VA, Ramsey D, McLaurin J, et al. Progression of lung inflammation and damage in rats sfter cessation of silica inhalation. Toxicol Sci. 2004; 79(2):370-380.

10. Cobben NA, Drent M, Schols AM, Lamers RJ, Wouster EF, Van Dieijen-Visser MP. Serum lactate dehydrogenase and its isoenzyme pattern in ex-coalminers. Respir Med. 1997;91(10): 616-623.

11. Kishimoto T. Interleukin-6: from basic science to medicine-40 years in immunology. Annu Rev Immunol. 2005;23:1-21.

12. Garrod R, Marshall J, Barley E, Fredericks S, Hagan G. The relationship between inflammatory markers and disability in chronic obstructive pulmonary disease (COPD). Prim Care Respir J. 2007;16(4):236-240.

13. International Labor Organization. International Labor Organization Guidelines for the use of the ILO international classification of radiographs of pneumoconiosis. Revised Edition 2000. (Occupational Safety and Health Series, No. 22.). Geneva: ILO Press; 2002.

14. Miller MR, Hankinson J, Brusasco V, Burgos F, Casaburi R, Coates A, et al. Standardisation of spirometry. Eur Respir J. 2005;26(2):319-338.

15. Morris JF, Koski A, Johnson LC. Spirometric standards for healthy nonsmoking adults. Am Rev Respir Dis. 1971;103: 57-67.
16. Korean Academy of Tuberculosis and Respiratory Diseases. Guideline for COPD and Asthma. Seoul: Seoul Medcus; 2005. p26-27.

17. Hnizdo E, Vallyathan V. Chronic obstructive pulmonary disease due to occupational exposure to silica dust: a review of epidemiological and pathological evidence. Occup Environ Med. 2003;60(4):237-243.

18. Vanhee D, Molet S, Gosset P, Tillie-Leblond I, Boitelle A, Wallaert B, et al. Expression of leukocyte-endothelial cell adhesion molecules is limited to intercellular adhesion molecule-1 (ICAM-1) in the lung of pneumoconiotic patients: role of tumor necrosis factor-alpha (TNF- $\alpha$ ). Clin Exp Immunol. 1996; 106(3):541-548.

19. Drent M, Cobben NA, Henderson RF, Wouters EF, van Dieijen-Visser M. Usefulness of lactate dehydrogenase and its isoenzymes as indicators of lung damage or inflammation. Eur Respir J. 1996; 9:1736-1742.

20. Pepys MB, Hirschfield GM. "C-reactive protein: a critical update". J Clin Invest. 2003;111(12):1805-1812.

21. Fernandez Rego G, Ocio Achaerandio G, Gonzalez Cuervo V, Rodriquez Menendez C, Martinez Gonezalez C, Alvarez Alvarez, C. Presence of acute phase response in coal workers' pneumoconiosis. Br J Ind Med. 1991;48(3):193-195.

22. Agusti A, Edwards LD, Rennard SI, MacNee W, Tal-Singer R, Miller BE, et al. Persistent systemic inflammation is associated with poor clinical outcomes in COPD: A novel phenotype. PLoS One 2012;7(5):e37483. 